\title{
Challenges of the Automotive Industry Regarding Pollutants Emissions Control
}

\author{
Sérgio Leal Soares and Eduardo Hiroaki Nishi \\ MWM INTERNATIONAL Motores
}

E-mail: sergio.soares@ navistar.om.br, eduardo.nishi@ navistar.com.br

\begin{abstract}
Society and government have shown great interest in improving people's quality of life in many ways. Sustainability issues have become very common in many discussions and debates, in the pursuit of a commitment to produce the necessary goods and the preservation of the environment. This involves improvements in all aspects of production and economic activities. The idea is to positively influence the conservation of the environment in which we live, avoiding compromising the future of this and the next generations.
\end{abstract}

A very sensitive parameter to the balance of sustainability is the atmospheric air of places that have productive and economic activities, mainly large urban centers because they are places of great presence of polluting sources (industries, motor vehicles, etc). Many diseases, mainly respiratory and cardiovascular, are related to air quality.

According to Azuaga (2000), atmospheric pollution can be defined as the presence of harmful substances in the atmosphere in sufficient quantity to affect its composition or equilibrium, damaging the environment and the most varied life forms.

Motor vehicles, in particular, release a significant part of the emission of polluting gases into the atmosphere. The constant increase of the fleet of vehicles in big cities makes the environment even more loaded with toxic gases, with negative consequences for the health of the people.

The idea of this work is to present the main pollutant gases from motor vehicles and their consequences for human health, to know the measures imposed by the government to reduce and control the levels of these pollutants, to be aware of the technologies that contribute to minimize the generation of these gases and also the proposals to reduce these negative impacts.

\section{INTRODUCTION}

Around the world there are several cities with large concentrations of people, developing economic activities and generating enormous amount of waste. A good part of this waste, the 
polluting gases, is poured daily in the air, causing negative consequences for the inhabitants that live there.

Due to the constant need to grow economically, many countries do not care about the future problems that air pollution causes to the health of people and the environment.

Developing countries are the most uncontrollable, such as China and India. They have cities with a regrettable history of chronic diseases in their inhabitants, especially children and the elderly, who are more sensitive to the evils caused by pollution.

Efforts and policies to control pollutant emissions must be seriously monitored by governments to avoid people's health problems.

There are several actions to enable the control of pollutant emissions. In this work, the methodology, air evaluation and motor vehicles pollution control methods will be discussed.

\section{ENGINEERING FUNDAMENTALS}

Internal combustion engines are used in vehicles with the aim of transforming the chemical energy generated during the burning of the air with the fuel in mechanical energy, which provides the traction for the displacement and other applications according to the necessity of the vehicle.

Although engines have an undeniable importance for people's lives, they generate negative consequences and the main one is the production of gaseous pollutants that may prejudice people's health.

Teixeira et al. (2008) states that emissions caused by motor vehicles carry a wide variety of toxic substances that when in contact with the respiratory system, can have the most diverse negative effects on health.

Ambient air receives daily a large amount of pollutant gases expelled by industries and motor vehicles. There are several types of gases and their consequences for people's health and the environment are varied.

According to Carvalho (2009), among the various forms of environmental degradation, atmospheric air pollution is one of the most damaging to civilization, affecting human health, ecosystems and historical cultural heritage, as well as the climate.

Below they are related and analyzed in more detail. 


\subsection{Particulate Matter}

Particulate matter is any solid compound that is suspended in the ambient air. It comes from various sources such as the vehicle exhaust pipe, industry chimneys, plus dust raised by the wind and vehicle movement.

According to Almeida (1999) these particles vary considerably in size, morphology, chemical composition and physical properties.

The size of these particles has a major influence on people's health: the smaller the size (10 or 2.5 microns), the more easily it will go deep into the respiratory system, causing serious illnesses (asthma, bronchitis, etc.).

\subsection{NOx (nitrogen oxides)}

Nitrogen oxides refer to several gaseous chemical compounds, formed by the joining of oxygen and nitrogen. They are formed in combustion at high temperatures where the air is the oxidizer. Nitrogen oxides are very polluting gases emitted into the atmosphere by internal combustion engines, furnaces, boilers, greenhouses, incinerators, among others.

\subsection{CO (carbon monoxide)}

Carbon Monoxide is a gas produced by burning under conditions of low oxygen (incomplete combustion) and high temperature of coal or other carbon-rich materials, such as petroleum products. It is slightly flammable, colorless, odorless and very dangerous due to its high toxicity.

\subsection{HC (hydrocarbon)}

Hydrocarbons resulting from combustion are fuel molecules that have not been burned or have undergone only partial oxidation.

According to Almeida (1999) the hydrocarbons can react with other substances, such as oxygen, nitrogen, chlorine and sulfur and form a great variety of derivative compounds.

\subsection{O3 (ozone)}

Ozone is a gas composed of 3 oxygen atoms, invisible, strongly reactive and with characteristic odor. It is of great importance when it is in the upper atmosphere, protecting the planet from the ultraviolet rays of the sun, but it is harmful when it is formed near the earth's surface, becoming a pollutant. 
It is formed by the reaction of hydrocarbons and nitrogen oxides found in the air with solar radiation.

Ozone is the most difficult pollutant to control because it is not emitted directly into the atmosphere, being formed near the surface of the Earth through reactions with strong solar radiation and dry weather.

\subsection{Aldehydes}

Aldehydes are chemical compounds resulting from the partial oxidation of alcohols or from photochemical reactions in the atmosphere, involving hydrocarbons.

They are emitted in the burning of fuel in automotive vehicles, mainly in the vehicles equipped with motors moved by ethanol. The aldehydes emitted by the cars are Formaldehyde and in greater quantity Acetaldehyde.

\section{7. $\mathrm{SO}_{2}$ (sulfur dioxide) and acid aerosols}

$\mathrm{SO}_{2}$ is produced during the burning of fossil fuels such as petroleum, usually from automobiles and thermoelectric plants. The $\mathrm{SO}_{2}$ in the atmosphere is oxidized and forms sulfuric acid $\left(\mathrm{H}_{2} \mathrm{SO}_{4}\right)$. This process of change depends on the time it remains in the air, the presence of sunlight, temperature, humidity and adsorption of the gas on the surface of the particles. When $\mathrm{SO}_{2}$ remains suspended for a long time in the air, it is possible for it to be carried by the winds to distant places, increasing the area of contamination of this pollutant and its derivatives (acid aerosols).

\subsection{Types of fuels used in motor vehicles}

Automotive vehicles use fuels in the combustion of their engines to generate mechanical energy.

These fuels are mostly of mineral origin and have unwanted residues in their composition that can be even more damaging to emissions if they are not controlled.

Below are the most commonly used motor vehicle fuels today.

\subsubsection{Diesel}

Diesel oil is a fuel derived from petroleum, widely used in trucks, tractors, vans, locomotives, passenger cars, large machines and boats. It is formed by hydrocarbons (chemical compound formed by atoms of hydrogen and carbon) besides possessing in their composition, in small amount, oxygen, nitrogen and sulfur. 
Diesel is presented in the form of viscous yellowish liquid, clear, low volatility and strong smell.

\subsubsection{Ethanol}

Ethanol is an alcohol of vegetable origin used as fuel in vehicles. The great advantage of this fuel is that it comes from a renewable source.

In Brazil, ethanol is used to supply vehicles in isolated form as hydrated alcohol, alcohol and water mixture that needs to be $95,1 \%$ to $96 \%$ alcoholic strength and mixed with gasoline in the form of anhydrous alcohol. This blend is currently $25 \%$ alcohol in gasoline.

Ethanol can be extracted from a variety of raw materials, including sugarcane, corn, wheat and barley, the most productive and most used sugarcane in Brazil, where the manufacturing process is carried out in large plants.

\subsubsection{Gasoline}

Gasoline is a fuel derived from petroleum, consisting of hydrocarbons and, to a lesser extent, from oxygenated products. These hydrocarbons are generally lighter than those that make up diesel oil. Gasoline may also contain sulfur compounds and nitrogen containing compounds.

\subsection{Effects of pollution on human health}

Carbon monoxide is an extremely dangerous gas that can lead to death. Several symptoms are noticed by a person who has inhaled this gas for a time such as headaches and chest pain, dizziness, confusion, weakness, nausea and vomiting, and may lead to loss of consciousness and death. There is a risk of cardiac and neural sequelae following intoxication.

Carbon monoxide, after being inhaled and distributed in the bloodstream, combines with hemoglobin to form carboxyhemoglobin, decreasing the amount of hemoglobin available for oxygen transport, reducing blood oxygenation.

According to Braga et al. (2001) carbon monoxide has an affinity for hemoglobin 240 times greater than that of oxygen, which means that a small amount of $\mathrm{CO}$ can saturate a large amount of hemoglobin molecules, reducing the ability of the blood to carry $\mathrm{O}_{2}$.

Carbon monoxide is able to inhibit the exchange of oxygen in the blood with vital tissues and, at high concentrations, can lead to death by poisoning, primarily affecting the cardiovascular and nervous system.

The particulate material is another polluting element expelled by motor vehicles. It can cause serious respiratory and cardiac problems, especially in the elderly and children, due to their more fragile health.

Gouveia et al. (2006) identified an association of inhalable particulate matter with a $4.6 \%$ increase in hospitalizations for asthma in children, $4.3 \%$ for chronic obstructive pulmonary disease in the elderly and $1.5 \%$ for ischemic heart disease in the elderly. 
According to Freitas et al. (2004) there is a relation between the increase of ozone in the environment with people with respiratory diseases. In addition, it can also cause eye irritation, reduced lung capacity, aggravation of respiratory diseases, interference with photosynthesis and damage to outdoor works of art and metal structures.

According to Coelho (2007) nitrogen dioxide $\left(\mathrm{NO}_{2}\right)$ at high levels can cause serious breathing problems, especially in children. People with asthma may face their health worse by having contact with this pollutant.

In relation to sulfur dioxide $\left(\mathrm{SO}_{2}\right)$, Freitas et al. (2004) report that this element is easily absorbed by the respiratory system, generating serious risks to health. Nascimento et al. (2004) found a positive correlation between sulfur dioxide and the number of hospitalizations due to respiratory diseases.

Aldehydes, on the other hand, have negative effects on the mucous membranes, eyes, nose and respiratory tract in general, and can cause asthmatic attacks, as well as potential carcinogenic compounds.

\subsection{Effects of pollution in the environment}

\subsubsection{Acid rain}

Acid rain is thus called any form of atmospheric precipitation whose acidity is greater than that of the atmospheric carbon dioxide $\left(\mathrm{CO}_{2}\right)$ dissolved in the precipitated water. The acidity of acid rain is caused by sulfur and nitrogen reactive gases and patinas whose hydrolysis in the atmospheric environment produces strong acids. Particularly important are the nitrogenous compounds (NOx) generated by the high burning temperatures of fossil fuels and the sulfur compounds (SOx) produced by the oxidation of sulfur impurities in most coal and oil. The environmental effects of acid rain pose serious problems for the health of people and animals.

\subsubsection{Greenhouse effect}

Greenhouse effect is the retention of radiation in the atmosphere emitted by the earth's surface, preventing it from being released into space. The principle of this radiation is the Sun, which gives the space a large amount of radiation at different wavelengths, where some are possible to be visible and others only visualized with specific equipment, such as ultraviolet. A good part of the solar radiation is reflected as soon as it reaches the terrestrial atmosphere, something around 33\%. The rest can penetrate the atmosphere and reach the earth's surface (continents and oceans). Therefore, the earth's surface is heated. The greenhouse effect, despite being a natural phenomenon, is increased because of the burning of fossil fuels that represent the increasing increase of human and industrial activities. The main greenhouse gases are water vapor $\left(\mathrm{H}_{2} \mathrm{O}\right)$ and carbon dioxide $\left(\mathrm{CO}_{2}\right)$. Methane $\left(\mathrm{CH}_{4}\right)$, nitrous oxide $\left(\mathrm{N}_{2} \mathrm{O}\right)$, ozone $\left(\mathrm{O}_{3}\right)$, various chlorofluorocarbons and many others present in small quantities also contribute to the production of the effect. Although they are transparent to the radiation in the range of visible light, they are heat radiation retainers. 


\subsection{Levels of acceptance of air quality}

The World Health Organization has defined some air quality standards that depend on various factors such as health risks, technical feasibility, economic considerations and various other political and social factors, as well as the country's ability to manage air quality.

An air quality standard defines a maximum limit for the concentration of an atmospheric component. These standards are based on scientific studies verifying the effects produced by specific pollutants and are set at levels that can provide an adequate margin of safety. protect the health and well-being of people. (Lisbon and Kawano, 2007).

Brazil established air quality standards through CONAMA Resolution 3/1990, thus dividing primary and secondary standards and thus named air quality standards (PQAr).

Table 1 shows the maximum values established and the method used to evaluate the air. This evaluation is performed by monitoring units distributed throughout the country, thus mapping the air conditions at various points for studies and possible actions to control pollution.

Table 1 - National standards for air quality (CONAMA Resolution No. 03 of June 28, 1990).

\begin{tabular}{|c|c|c|c|c|}
\hline Pollutant & Sampling Time & $\begin{array}{l}\text { Primary Pattern } \\
\qquad\left(\mu \mathrm{g} / \mathrm{m}^{3}\right)\end{array}$ & $\begin{array}{l}\text { Secondary Pattern } \\
(\mu \mathrm{g} / \mathrm{m} 3)\end{array}$ & Measurement Method \\
\hline \multirow{2}{*}{ total suspended particulates } & 24 hours $^{1}$ & 240 & 150 & \multirow{2}{*}{ large volume sampler } \\
\hline & GMA & 80 & 60 & \\
\hline \multirow{2}{*}{ inhaled particles } & 24 hours $^{1}$ & 150 & 150 & \multirow{2}{*}{ Inertial separation / filtration } \\
\hline & AAM & 50 & 50 & \\
\hline \multirow{2}{*}{ smoke } & 24 hours $^{1}$ & 150 & 100 & \multirow{2}{*}{ reflectance } \\
\hline & AAM & 60 & 40 & \\
\hline \multirow{2}{*}{ sulfur dioxide } & 24 hours $^{1}$ & 365 & 100 & \multirow{2}{*}{ pararosaniline } \\
\hline & AAM & 80 & 40 & \\
\hline \multirow{2}{*}{ nitrogen dioxide } & 1 hour $^{1}$ & 320 & 190 & \multirow{2}{*}{ chemiluminescence } \\
\hline & AAM & 100 & 100 & \\
\hline \multirow{4}{*}{ carbon monoxide } & 1 hour 1 & 40000 & 40000 & \multirow{4}{*}{ infra red non-dispersive } \\
\hline & Inour & $35 \mathrm{ppm}$ & $35 \mathrm{ppm}$ & \\
\hline & \multirow{2}{*}{8 hours $^{1}$} & 10000 & 10000 & \\
\hline & & $9 \mathrm{ppm}$ & $9 \mathrm{ppm}$ & \\
\hline ozone & 1 hour $^{1}$ & 160 & 160 & chemiluminescence \\
\hline
\end{tabular}

\footnotetext{
1 - Should not be exceeded more than once a year

2 - GMA: geometric mean annual

3 - AAM: annual arithmetic mean
}

Source: Qualidade do ar no estado de São Paulo 2016

This control system and parameters consider that, if the primary standard is exceeded, pollution will affect the health of the population. Thus, the values of the primary standard are considered as the maximum concentration levels of air pollutants, thus constituted as short and medium-term goals. 
Secondary air quality standards indicate concentrations of air pollutants that do not consider effects on people's health and well-being, as well as disregarding damages to fauna and flora, materials and the environment in general. They can be understood as desired concentration levels of pollutants, constituting a long-term goal.

In 2013, the State of São Paulo defined new parameters for assessing air quality, making it more judicious. Find below these data in Table 2.

Table 2 - State Standards for Air Quality (State Decree No. 59113 of 04/23/2013).

\begin{tabular}{|c|c|c|c|c|c|c|}
\hline Pollutant & Sampling Time & \multicolumn{1}{|c|}{$\mathrm{MI}\left(\mu \mathrm{g} / \mathrm{m}^{3}\right)$} & $\mathrm{MI}\left(\mu \mathrm{g} / \mathrm{m}^{3}\right)$ & $\mathrm{MI3}\left(\mu \mathrm{g} / \mathrm{m}^{3}\right)$ & $\mathrm{PF}\left(\mu \mathrm{g} / \mathrm{m}^{3}\right)$ \\
\hline \multirow{2}{*}{ inhaled particles $\left(\mathrm{MP}_{10}\right)$} & 24 hours & 120 & 100 & 75 & 50 \\
\cline { 2 - 6 } & AAM & 40 & 35 & 30 & 20 \\
\hline \multirow{2}{*}{ fine inhalable particles $\left(\mathrm{MP}_{2,5}\right)$} & 24 hours & 60 & 50 & 37 & 25 \\
\cline { 2 - 6 } & AAM & 20 & 17 & 15 & 10 \\
\hline \multirow{2}{*}{ sulfur dioxide $\left(\mathrm{SO}_{2}\right)$} & 24 hours & 60 & 40 & 30 & 20 \\
\cline { 2 - 6 } & AAM & 40 & 30 & 20 & - \\
\hline \multirow{2}{*}{ nitrogen dioxide $\left(\mathrm{NO}_{2}\right)$} & 1 hour & 260 & 240 & 220 & 200 \\
\cline { 2 - 6 } & AAM & 60 & 50 & 45 & 40 \\
\hline \multirow{2}{*}{ ozone $\left(\mathrm{O}_{3}\right)$} & 8 hours & 140 & 130 & 120 & 100 \\
\hline carbon monoxide $(\mathrm{CO})$ & 8 hours & - & - & - & $9 \mathrm{ppm}$ \\
\hline \multirow{2}{*}{ smoke } & 24 hours & 120 & 100 & 75 & 50 \\
\cline { 2 - 6 } & AAM & 40 & 35 & 30 & 20 \\
\hline \multirow{2}{*}{ total suspended particulates } & 24 hours & - & - & - & 240 \\
\cline { 2 - 6 } & GMA & - & - & - & 80 \\
\hline ** lead $(\mathrm{Pb})$ & GMA & - & - & - & 0,5 \\
\hline
\end{tabular}

1- AAM: annual arithmetic mean

2 - GMA: geometric mean annual

* Smoke and Total Particles in Suspension: Auxiliary parameters to be used only in specific situations, at the discretion of CETESB

** Lead: to be monitored only in specific areas, at CETESB's discretion

Source: Qualidade do ar no estado de São Paulo 2016

According to CETESB (2017), the Intermediate Targets must be met in three (3) steps, as follows:

I. Intermediate Target Step 1 - (MI1) - Concentration values of air pollutants that must be attended from 04/24/2013;

II. Intermediate Target Step 2 - (MI2) - Concentration values of air pollutants that must be respected subsequent to MI1, which will take effect after evaluations carried out in Step 1, revealed by technical studies presented by the state environmental agency, validated by CONSEMA;

III. Intermediate Goal Step 3 - (MI3) - Concentration values of air pollutants that must be respected in the years following MI2, and their duration will be defined by CONSEMA, from the beginning of its validity, based on the evaluations carried out in Step 2. 
The parameters regulated by the environmental legislation are as follows on the Table 3: total suspended particles, smoke, inhalable particles, sulfur dioxide, carbon monoxide, ozone and nitrogen dioxide. The same resolution also establishes the criteria for acute episodes of air pollution. It should be emphasized that the declaration of the states of Attention, Alert and Emergency requires, in addition to the levels of concentration reached, the forecast of meteorological conditions unfavorable to the dispersion of the pollutants.

Table 3 - Criteria for acute episodes of air pollution (State Decree No. 59113 of 04/23/2013).

\begin{tabular}{|c|c|c|c|}
\hline Parameters & Atention & Alert & Emergency \\
\hline fine inhalable particles $\left(\mu \mathrm{g} / \mathrm{m}^{3}\right)-24$ hours & 125 & 210 & 500 \\
\hline inhaled particles $(\mu \mathrm{g} / \mathrm{m} 3)-24$ hours & 250 & 420 & 2100 \\
\hline sulfur dioxide $(\mu \mathrm{g} / \mathrm{m} 3)-24$ hours & 800 & 1600 & 3000 \\
\hline nitrogen dioxide $(\mu \mathrm{g} / \mathrm{m} 3)-1$ hour & 1130 & 2260 & 40 \\
\hline carbon monoxide $(\mathrm{ppm})-8$ hours & 15 & 30 & 600 \\
\hline
\end{tabular}

Source: Qualidade do ar no estado de São Paulo 2016

\subsection{Techniques used to reduce gaseous emissions in motor vehicles}

\subsubsection{Improvement of fuels}

Sulfur is an undesirable element in fuel composition because of its corrosive effects on its compounds and the formation of highly toxic gases such as $\mathrm{SO}_{2}$ (sulfur dioxide) and $\mathrm{SO}_{3}$ (sulfur trioxide) by burning in the engines. With a lower sulfur content, the S-10 fuel that has $10 \mathrm{ppm}$ of sulfur in its composition is less polluting, bringing less harm to the environment and to people's health.

The Brazilian company that produces the fuels significantly reduced the amount of this element in its composition. The analysis made on the currently produced Diesel indicates sulfur concentration between 5 and 6 parts per million (ppm), quite below the $10 \mathrm{ppm}$ specified by the ANP itself to meet the Proconve determinations.

The Table 4 shows the evolution of process to reduce the Sulphur in the Diesel: 
Table $4-\mathrm{SO}_{2}$ - Evolution of sulfur content in Diesel

\begin{tabular}{|c|c|c|c|}
\hline \multirow{2}{*}{ Year } & \multicolumn{2}{|c|}{ Maximum sulfur } & \multirow{2}{*}{ Remarks } \\
\hline & Metropolitan & Country & \\
\hline 2006 & 500 & 2000 & \\
\hline 2009 & 500 & 1800 & $\begin{array}{l}\text { From 01/01/2009 the S-50 diesel (maximum content of } 50 \mathrm{mg} / \mathrm{kg} \text { of sulfur) has become be supplied to the captive } \\
\text { fleets of the city of São Paulo, replacing the S-500 diesel (up to } 500 \mathrm{mg} / \mathrm{kg} \text { of sulfur) }\end{array}$ \\
\hline 2010 & 500 & 1800 & From 01/01/2010 the supply of the $S-50$ diesel was extended to the fleets of the entire RMSP. \\
\hline 2012 & $50 / 500$ & 1800 & $\begin{array}{l}\text { From 01/01/2012 the S-50 diesel has been supplied in several service stations including the MSYP and other cities } \\
\text { in the State of São Paulo. }\end{array}$ \\
\hline 2013 & $10 / 500$ & $500 / 1800$ & $\begin{array}{l}\text { From 01/01/2013 the diesel S-10 (with content up to } 10 \mathrm{mg} / \mathrm{kg} \text { of sulfur) became } \\
\text { supplied at several filling stations in the country, replacing the S-50 diesel. }\end{array}$ \\
\hline 2014 & $10 / 500$ & 500 & $\begin{array}{l}\text { From 01/01/2014, the S-500 diesel has been supplied nationwide, in } \\
\text { replacement of the S-1800 diesel. }\end{array}$ \\
\hline
\end{tabular}

Source: Qualidade do ar no estado de São Paulo 2016

Another change in fuels was the addition of anhydrous ethanol to gasoline. Although this change caused increased fuel consumption and increased nitrogen oxide generation, it also significantly reduced carbon monoxide $(\mathrm{CO})$ production and increased the octane rating of gasoline.

Another quite significant change in fuel production was the removal of tetraethyl lead from its composition. The purpose of its use was to improve performance and economy in the operation of engines. The great problem observed in its use was the strong index of contamination with lead both among the people who handled it and with the environment. Brazil was one of the pioneers to solve this problem by adding alcohol in the composition of gasoline, eliminating the need for the use of lead.

\subsubsection{Exhaust gas treatment systems}

Diesel engines have a high efficiency by working with a high excess air factor and with a short fuel injection period close to the PMS. However, this rapid combustion leads to a considerable increase in the pressure inside the chamber and, therefore, generates hightemperature combustion peaks, resulting in the formation of NOx (nitrogen oxide).

The maximum amount of fuel injected must always comply with a range of excess air that should always be around 10 to $20 \%$ (Lambda between 1.1 and 1.2). This way the engine will be able to minimize the emitted particulate material. Particulate matter, along with NOx, are the main pollutants in the exhaust gas composition of a diesel engine.

Comparing the Otto cycle engine and without considering the aftertreatment performed by the catalytic converter, the diesel engine emits $\mathrm{CO}, \mathrm{HC}$ and $\mathrm{NOx}$ in smaller amounts. On the other hand, emissions of $\mathrm{SO}_{2}$ (sulfur dioxide) and particulate material are higher. 
Regarding the NOx emissions, still lower than those of the Otto cycle engine, they can not be reduced using three-way catalytic converter. This is because the diesel engine works with excess air, a fact that prevents the reductive action (transformation of NOx into free $\mathrm{O}_{2}$ and $\mathrm{N}_{2}$ ) of the three-way catalyst, which requires Lambda around 1 for maximum conversion efficiency. As a result, the reduction of NOx emissions in diesel engines has required the development of new types of catalysts.

Diesel engines have a very important commitment to NOx, particulate matter and fuel consumption. Methods that seek to reduce NOx always lead to increased fuel consumption. At the same time as reducing the NOx there is also an increase of the particulate material.

In order to reduce emissions and to ensure compliance with the most stringent emission standards, it was necessary to implement post-treatment solutions which resulted in the simultaneous reduction of both particulate and NOx.

It should be noted that the decrease in NOx emission can be obtained with both post-treatment and EGR methods.

The pollutant emissions to be controlled are $\mathrm{HC}, \mathrm{CO}$, particulate matter and $\mathrm{NOx}$ - a set of technologies must be applied for the control of $\mathrm{CO}, \mathrm{HC}$ and particulate and another for the control of NOx.

Figure 1 shows a complete system of components that improve the emissions of an engine. It is worth noting that the necessity of using these components will be in accordance with the legislation in which the engine must respect, not having the necessity of the use of all.

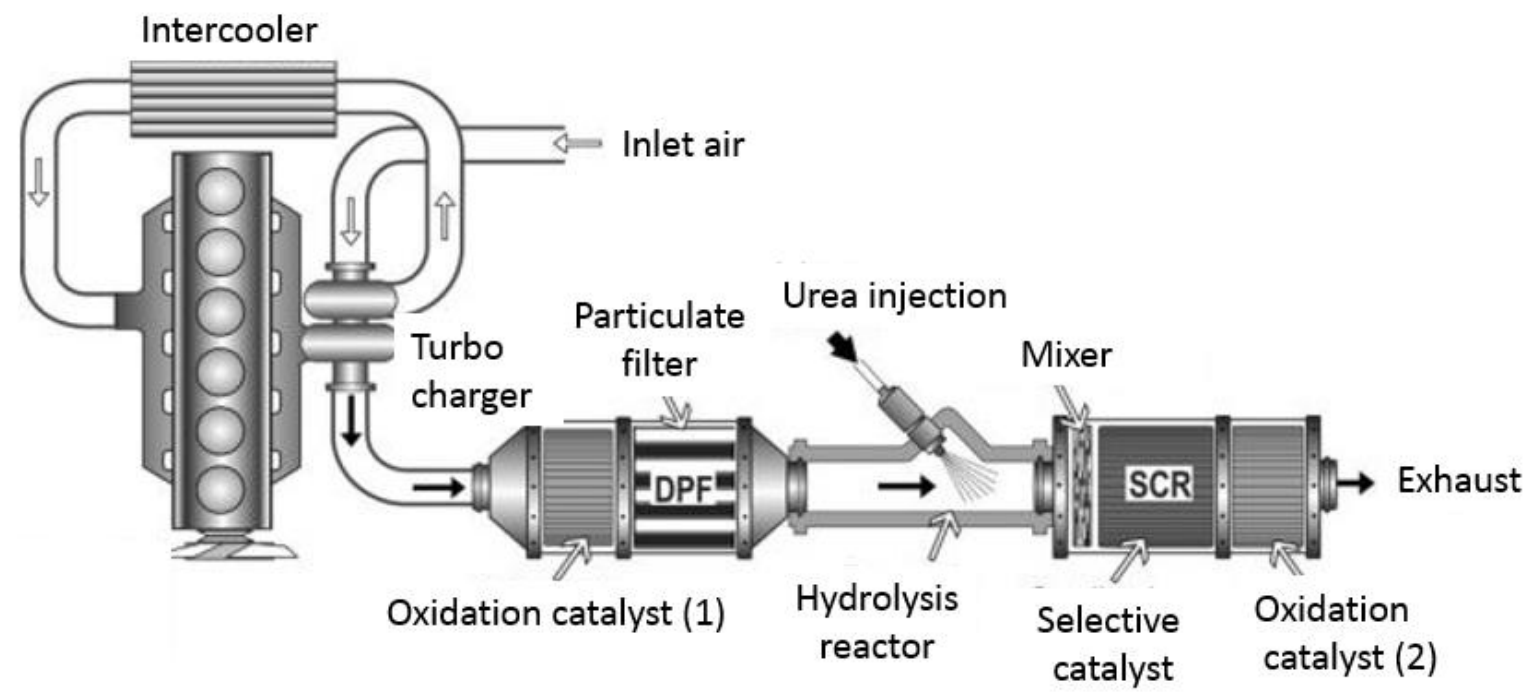

Figure 1 - Complete system of components that improve the emissions of an engine

The applied components work as follows: 
1. The oxidation catalyst [1] works with the objective of reducing $\mathrm{CO}$ and $\mathrm{HC}$ emissions, transforming into $\mathrm{CO}_{2}$ and $\mathrm{H}_{2} \mathrm{O}$.

2. The particulate filter (DPF) does not release the particulate material produced in the combustion. As the amount of particulate material in the filter increases, regeneration occurs through the combustion of the particles. This process occurs as follows: the engine injects the post-injection of fuel, a small amount of diesel that does not burn in the combustion chamber that ends up burning in the oxidizing catalyst [1]. This causes the gas temperature to rise. Thus, these reach the plateau of 500 degrees, which allows the spontaneous combustion of the particulate, regenerating the filter.

3. The SCR uses urea which, when reacted with the NOx from the combustion chamber combustion, results in $\mathrm{N}_{2}$ (nitrogen) and $\mathrm{H}_{2} \mathrm{O}$ (water) in the combustion chamber. The SCR catalysts are designed to reduce NOx emissions. The urea used in this vehicle application is obtained from a solution of $32 \%$ urea and the remaining water, dosed before the SCR catalyst. With the high temperature of the exhaust gases (above 170 degrees), the urea is transformed into ammonia in the hydrolysis reactor.

4. Finally, the oxidation catalyst [2] has the function of eliminating a possible excess of ammonia that has not reacted with the exhaust gas inside the SCR catalyst, transforming it into $\mathrm{N}_{2}$ (nitrogen) and $\mathrm{H}_{2} \mathrm{O}$ (water).

\subsubsection{Vehicle Inspection}

The purpose of the vehicle inspection is to verify that the vehicle maintenance is adequate to the assure that it does not influence the exhaust gas values. In addition, it assesses whether there has been any change in the original design of the vehicle that could also compromise emissions.

In the Otto cycle vehicles - gasoline, ethanol and CNG - an equipment called "Gas Analyzer" is used, which verifies the $\mathrm{HC}, \mathrm{CO}, \mathrm{O}_{2}$ and $\mathrm{CO}_{2}$ indices collected in the exhaust of the vehicle.

In Diesel Cycle vehicles - the degree of blackening of the smoke (denominated "opacity") is measured through the equipment called opacimeter. It checks the degree of opacity of the smoke by the frequency and wavelength of the infrared ray that passes through the smoke sample in the darkroom of the equipment.

Vehicle inspection is already adopted in many countries, such as Germany, Chile and Mexico.

The expected results of the vehicular inspection are the improvement of air quality, with the consequent improvement of public health and increase of the life expectancy of the inhabitants of the big cities. Reducing vehicular emissions directly reflects the issue of global warming and the issue of ozone concentration in the troposphere, which is responsible for the greenhouse effect. 


\section{Case study - Evaluation of air quality in the State of São Paulo}

The state of São Paulo has the largest population in Brazil and the largest vehicle fleet in the country, in addition to intense economic activity. Despite being satisfactory indicators, these indices have several negative consequences. One of them is a large production of polluting gases, which concerns the government and population, since it is known that the effects of pollution are negative on people's health, especially in the metropolitan area of São Paulo.

For this reason, the State of São Paulo was chosen in this study for a case study, in addition to having more studies published by government agencies.

The following is the study and information required to evaluate and conclude the efforts of government, entities, and vehicle manufacturers to maintain ambient air in acceptable conditions of survival.

\subsection{Vehicle fleet size}

Due to the ease of credit and incentives generated by the government, the São Paulo State vehicle fleet has been growing rapidly. This increase is noted in Figure 2, where it is fractionated by the vehicle category.

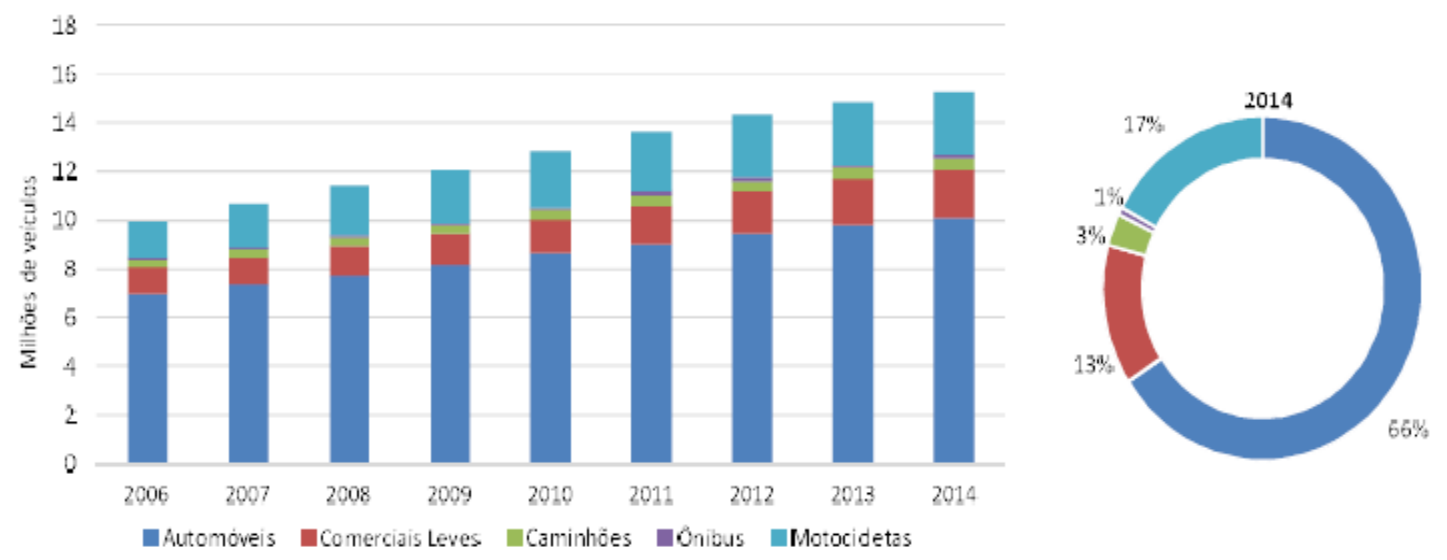

Figure 2 - Evolution of the current fleet in the State of São Paulo by category

Source: Emissões veiculares no estado de São Paulo 2014

This increase in the vehicle fleet results in an immediate increase in the amount of pollutant gases emitted into the atmosphere.

The Figure 3 shows the evolution of the fleet of heavy vehicles, separated by subcategory. 

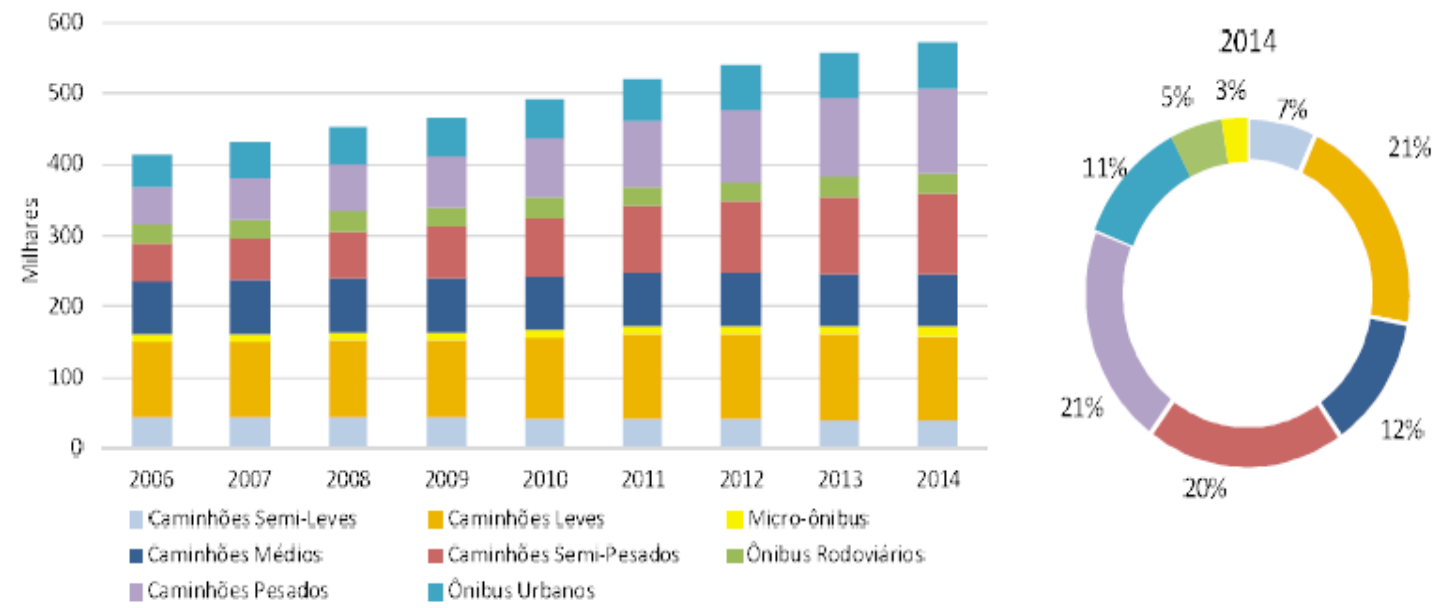

Figure 3 - Evolution of the circulating fleet of heavy vehicles by subcategory

Source: Emissões veiculares no estado de São Paulo 2014

\subsection{Vehicle fleet age}

Despite the increase in credit and facilities generated for the acquisition of new vehicles, a large amount of vehicles with many years of use and with lower levels of gaseous emissions control technology are still in circulation.

Figure 4 indicates the number of vehicles per category depending on the age of the vehicle.

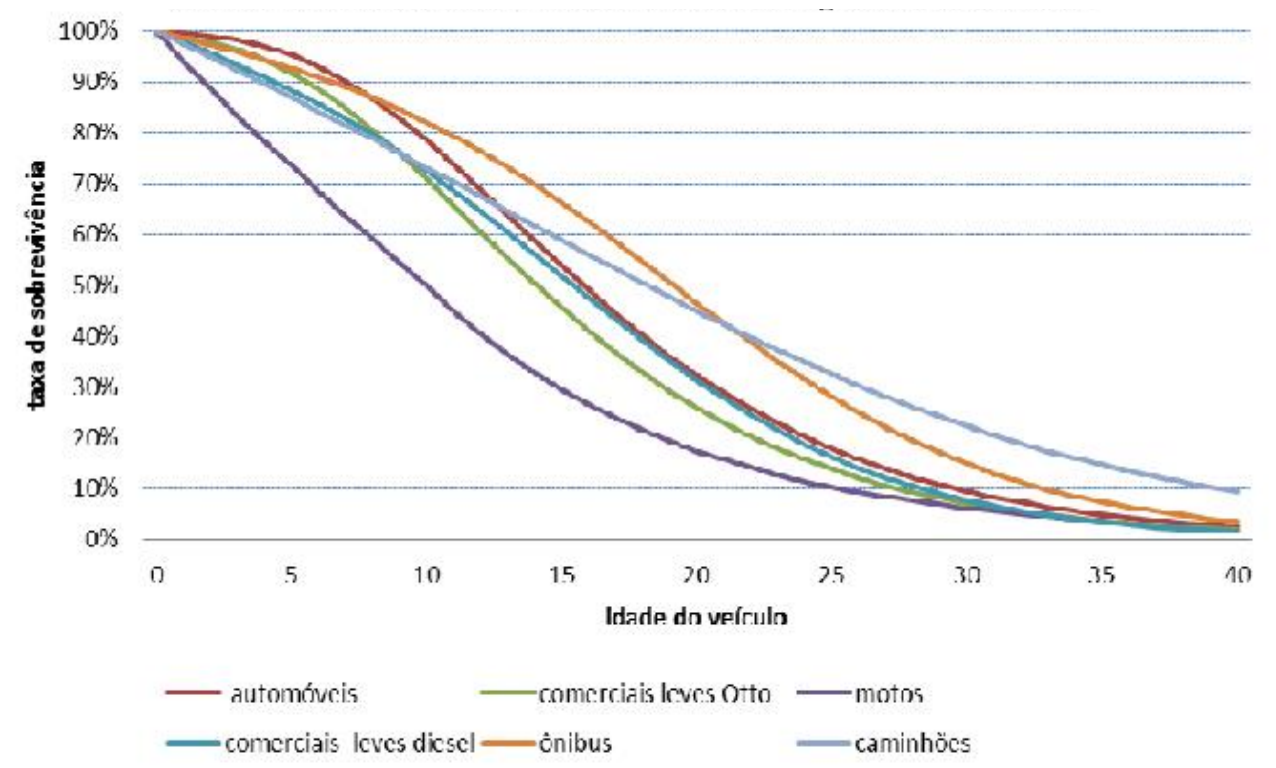

Figure 4 - Scrapbook curves for vehicle categories

Source: Emissões veiculares no estado de São Paulo 2014 
Figure 5 shows the evolution of the light commercial fleet by fuel type in the State of São Paulo. It is possible to observe that flex-fuel vehicles have had a large increase in participation in the last years, being currently the majority of this motorization.
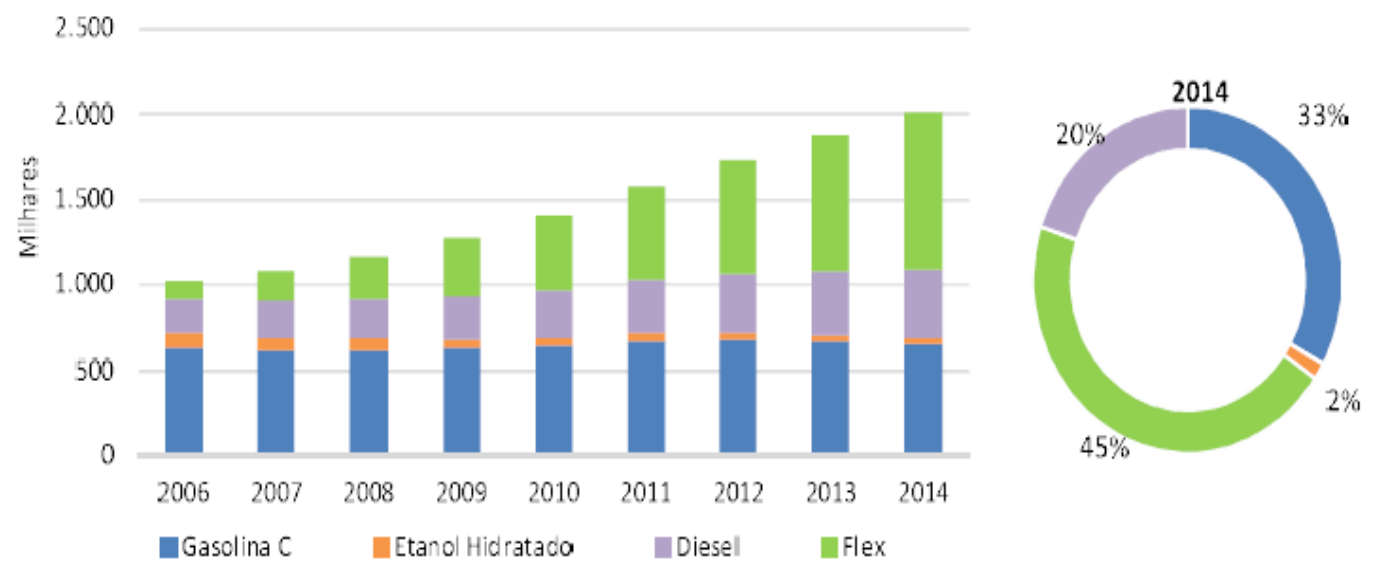

Figure 5 - Evolution of the light commercial fleet by type of fuel

Source: Emissões veiculares no estado de São Paulo 2014

\subsection{Emission of gaseous emissions from vehicles}

To better understand the level of pollution in the State of São Paulo, it is important to check the Figure 6:

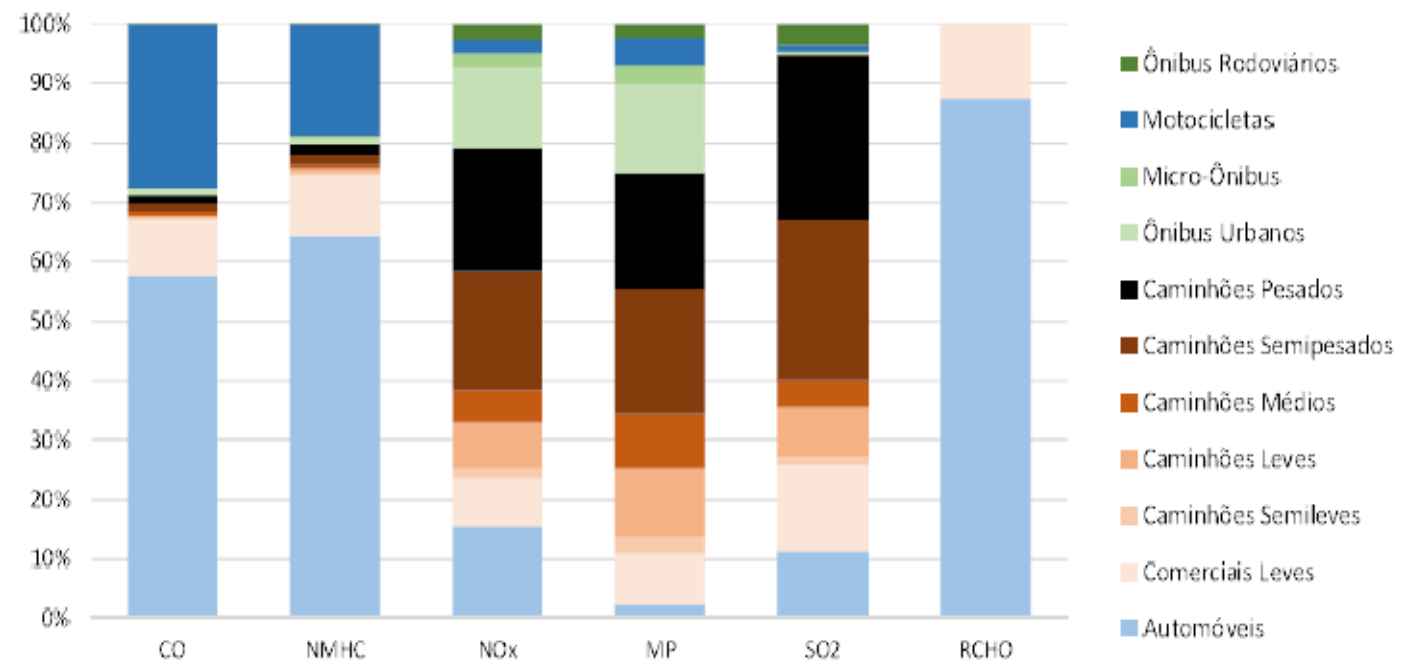

Figure 6 - Relative contribution of each category to the emission of pollutants in the State of São Paulo in 2014

Source: Emissões veiculares no estado de São Paulo 2014

Figure 7, 8 and 9 demonstrate the type of pollutant gas generated by motor vehicles and stratify the category of the vehicle and its respective contribution share. Based on this 
information it is possible to define strategies and permissions to use a certain category of vehicle in a certain location.
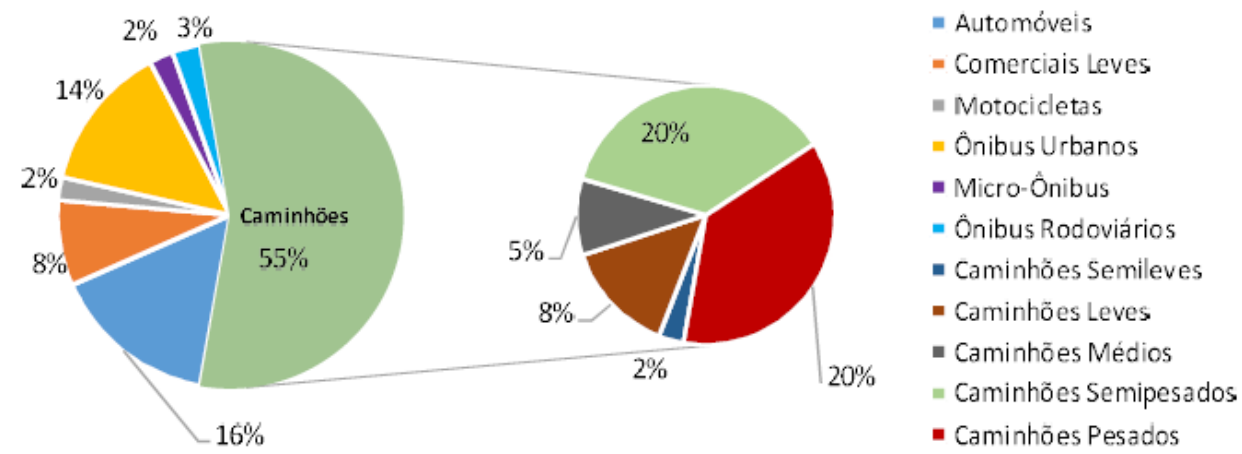

- Caminhōes Pesados

Figure 7 - Contribution of categories of vehicles in the emission of nitrogen oxides in the State of São Paulo in 2014

Source: Emissões veiculares no estado de São Paulo 2014

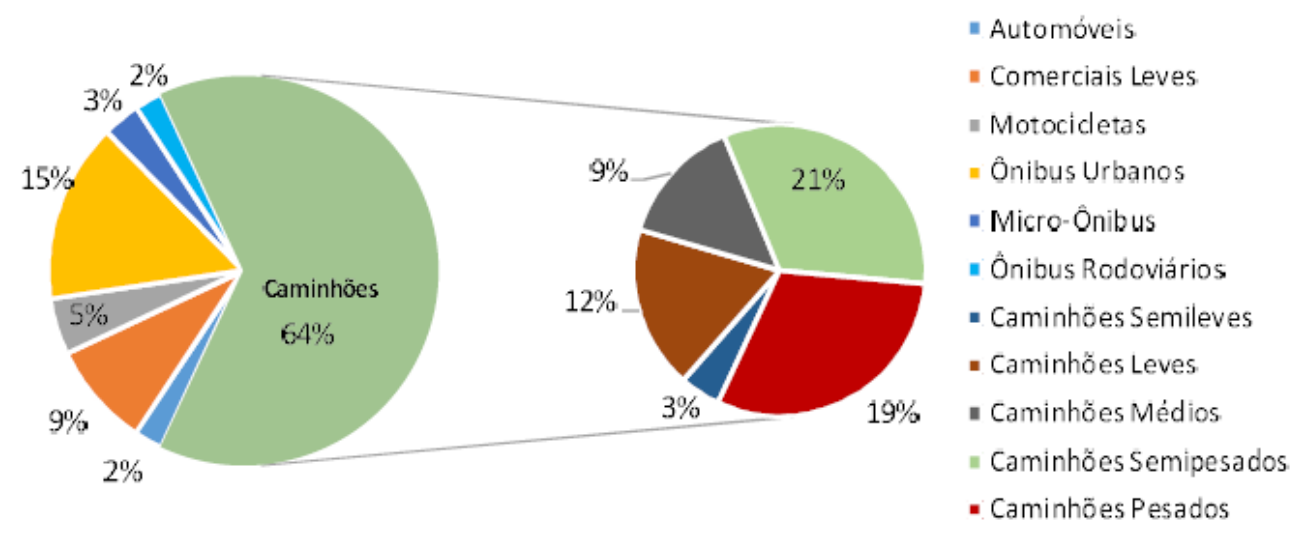

Figure 8 - Contribution of categories of vehicles in the emission of particulate matter in the State of São Paulo in 2014

Source: Emissões veiculares no estado de São Paulo 2014 


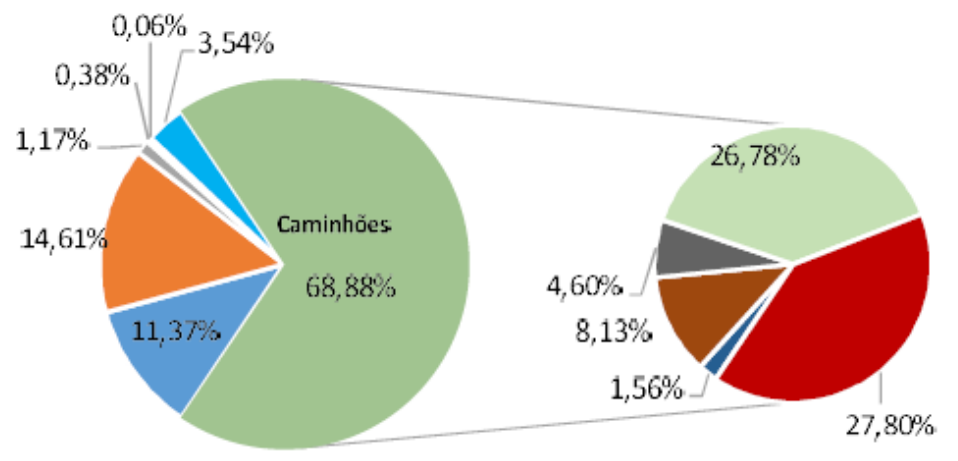

- Automóveis

- Comerciais Leves

= Motocicletas

= Onibus Urbanos

- Micro-Ônibus

- Ónibus Rodoviários

- Caminhöes Semileves

- Caminhöes Leves

- Caminhốes Médios

- Caminhöes Semipesados

- Caminhöes Pesados

Figure 9 - Contribution of vehicle categories to the emission of sulfur dioxide in the State of São Paulo in 2014

Source: Emissões veiculares no estado de São Paulo 2014

In addition to the stratification of the pollutants according to the category of the vehicle, there is also a survey of information on levels of pollutants over the years. Figures 10, 11, 12 and 13 show the amount of each pollutant in the São Paulo Metropolitan Region.

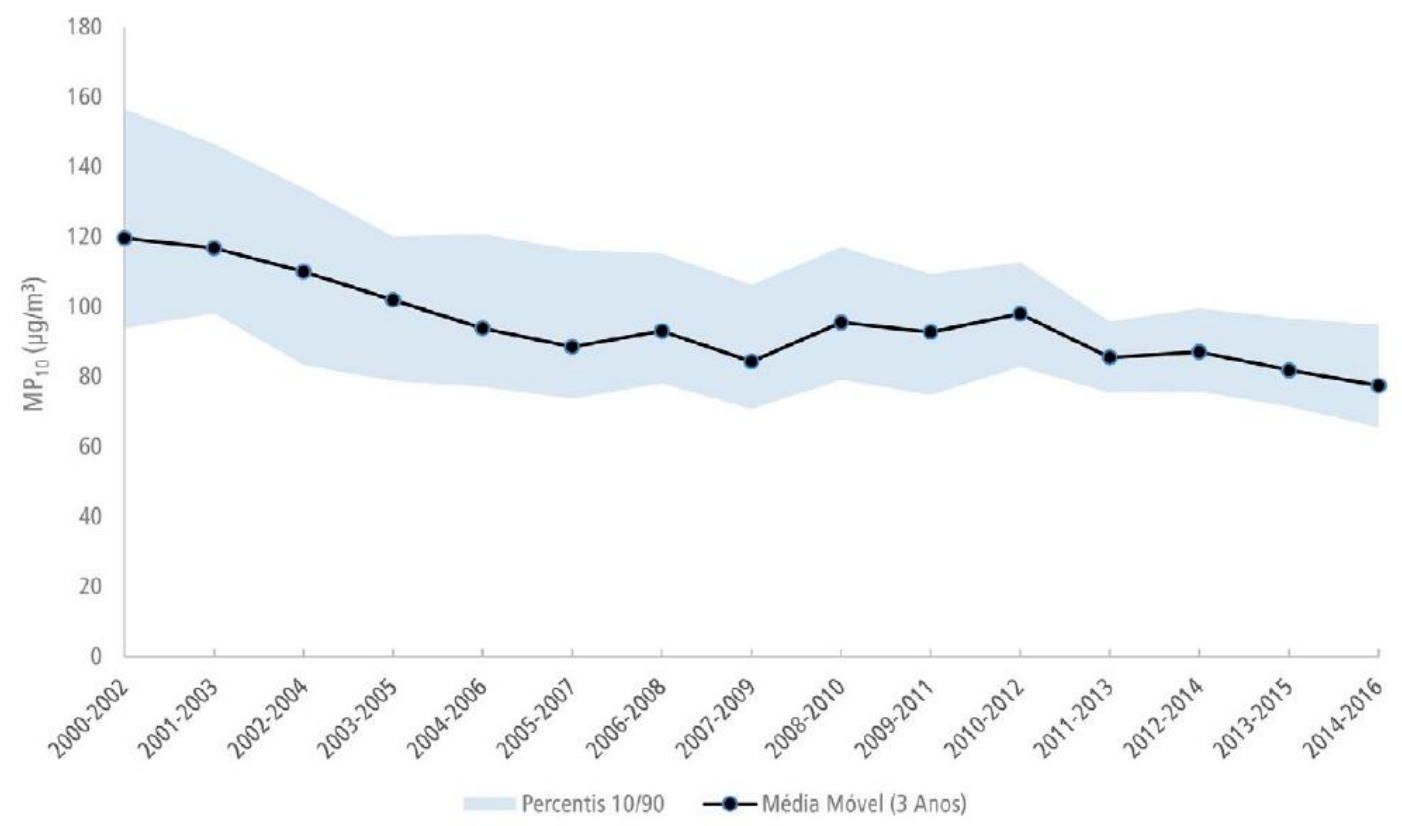

Figure 10 - MP10 - Evolution of the moving average of the 4th highest daily value (average of 24 hours)

Source: Qualidade do ar no estado de São Paulo 2016 


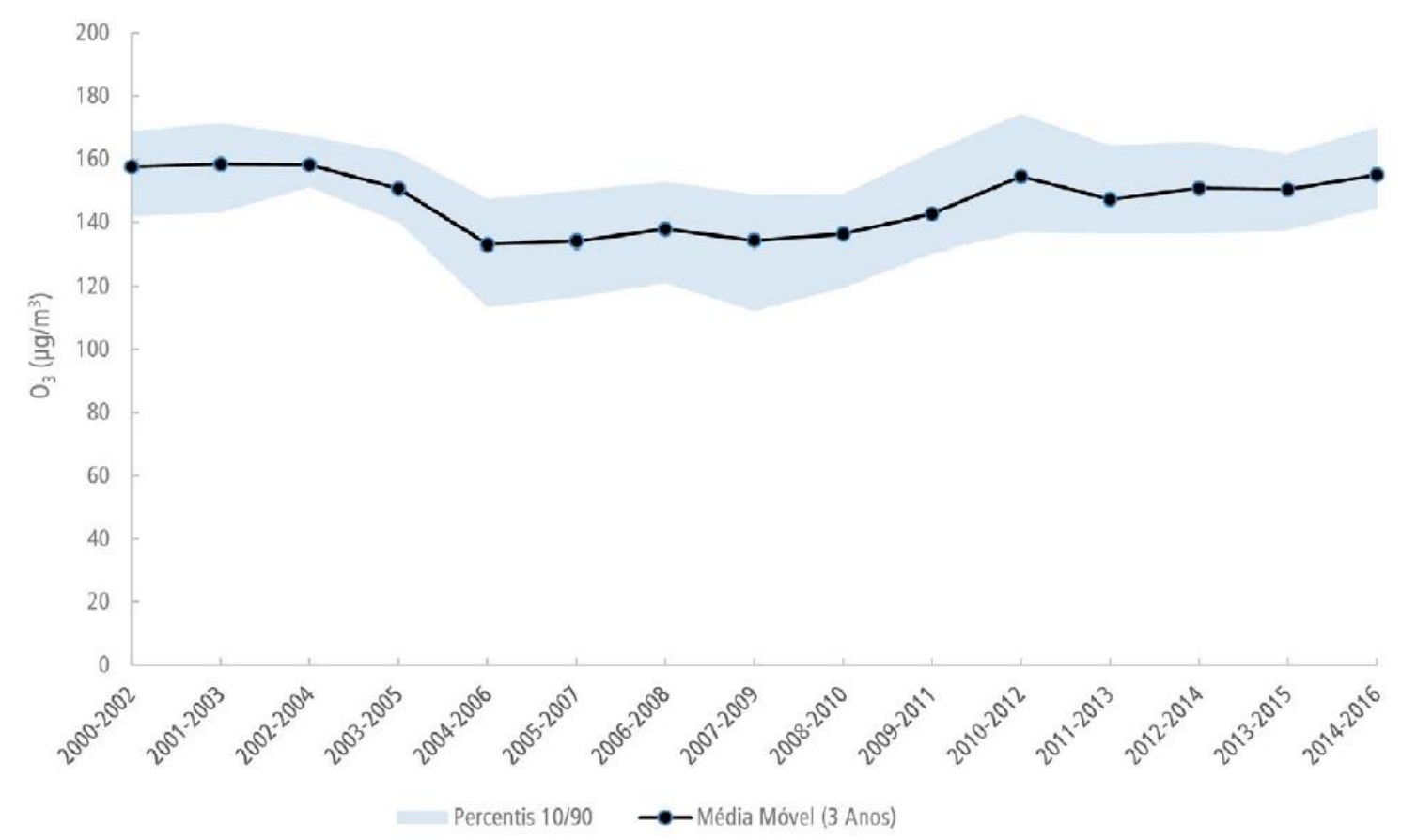

Figure $11-\mathrm{O}_{3}$ - Evolution of moving averages of the 4th highest daily value (maximum of $8 \mathrm{~h})$

Source: Qualidade do ar no estado de São Paulo 2016

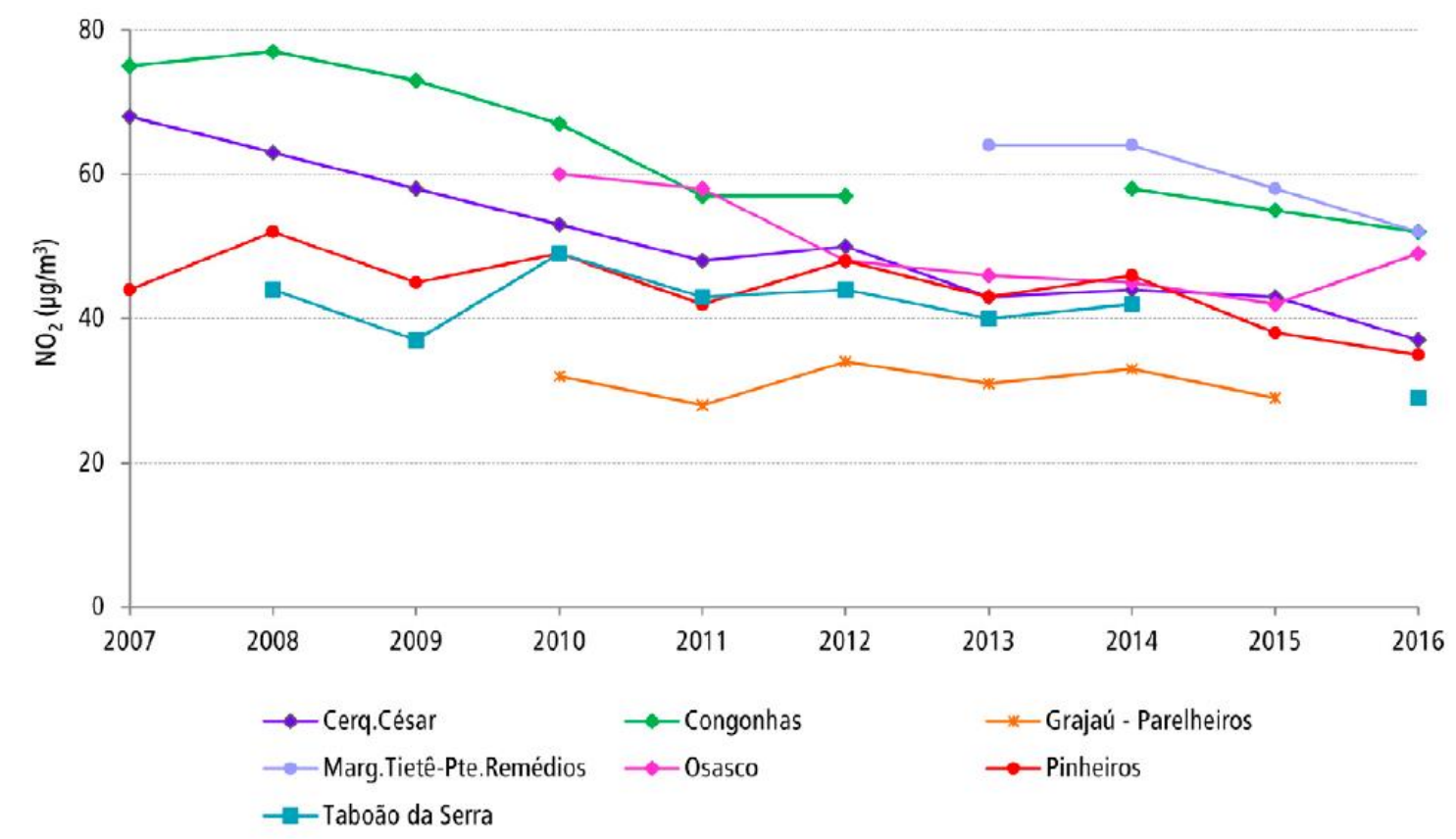

Figure $12-\mathrm{NO}_{2}$ - Evolution of annual average concentrations - RMSP - Micro scale Source: Qualidade do ar no estado de São Paulo 2016 


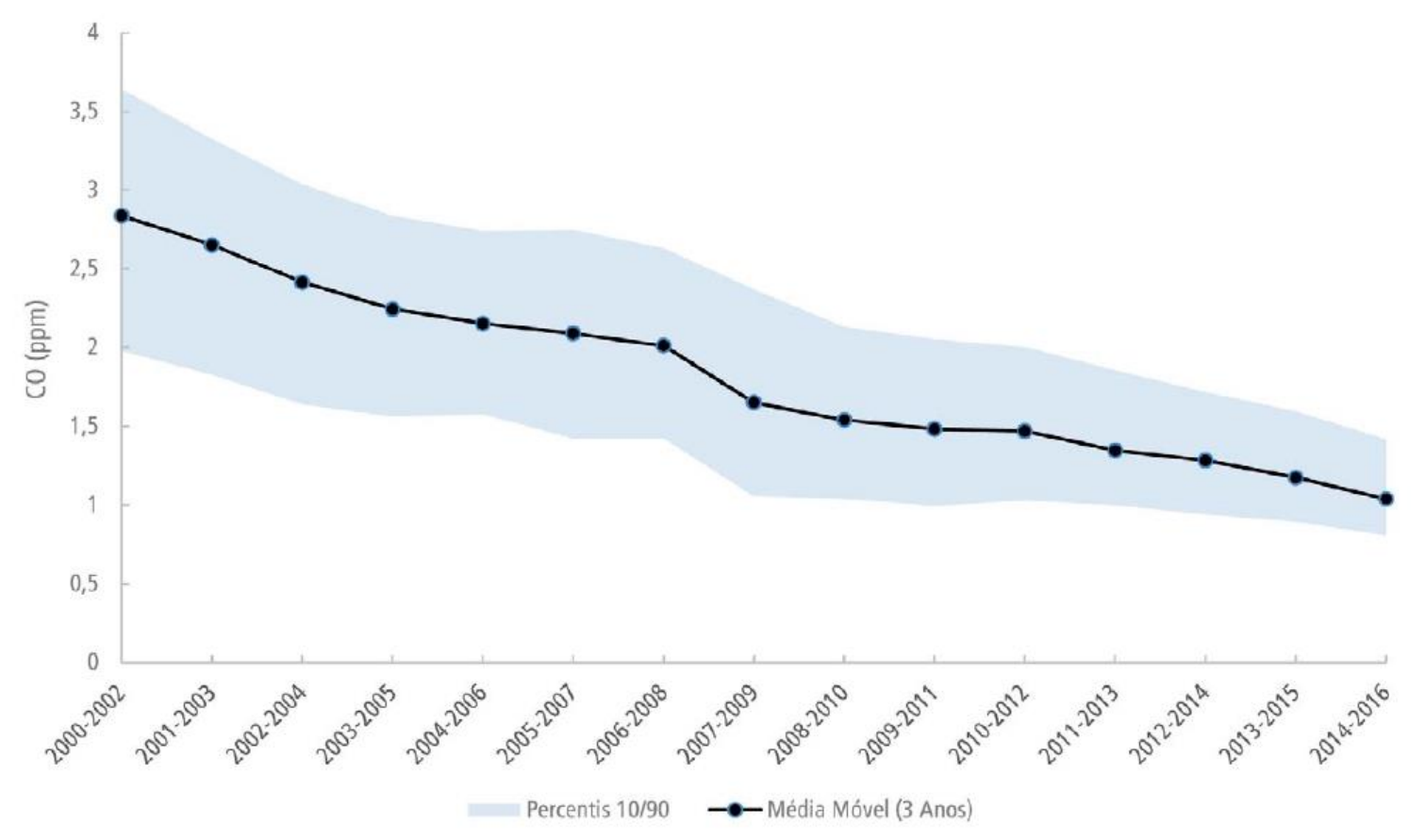

Figure 13 - CO - Evolution of moving averages of annual averages of maximum daily concentrations (mean of 8 hours)

Source: Qualidade do ar no estado de São Paulo 2016

Through the analysis of each graph it is possible to observe that as a general rule the various measured pollutant gases are reducing or maintaining their respective values over the years, even though there is an increase in the vehicular fleet in the State of São Paulo.

Decision-making to reduce sulfur in diesel and gasoline and the use of ethanol fuel, which is plant origin and does not have this component in its base, have positive results in relation to the amount of sulfur dioxide in the atmospheric air in the region metropolitan area of the State of São Paulo, as shown in Figure 14. 


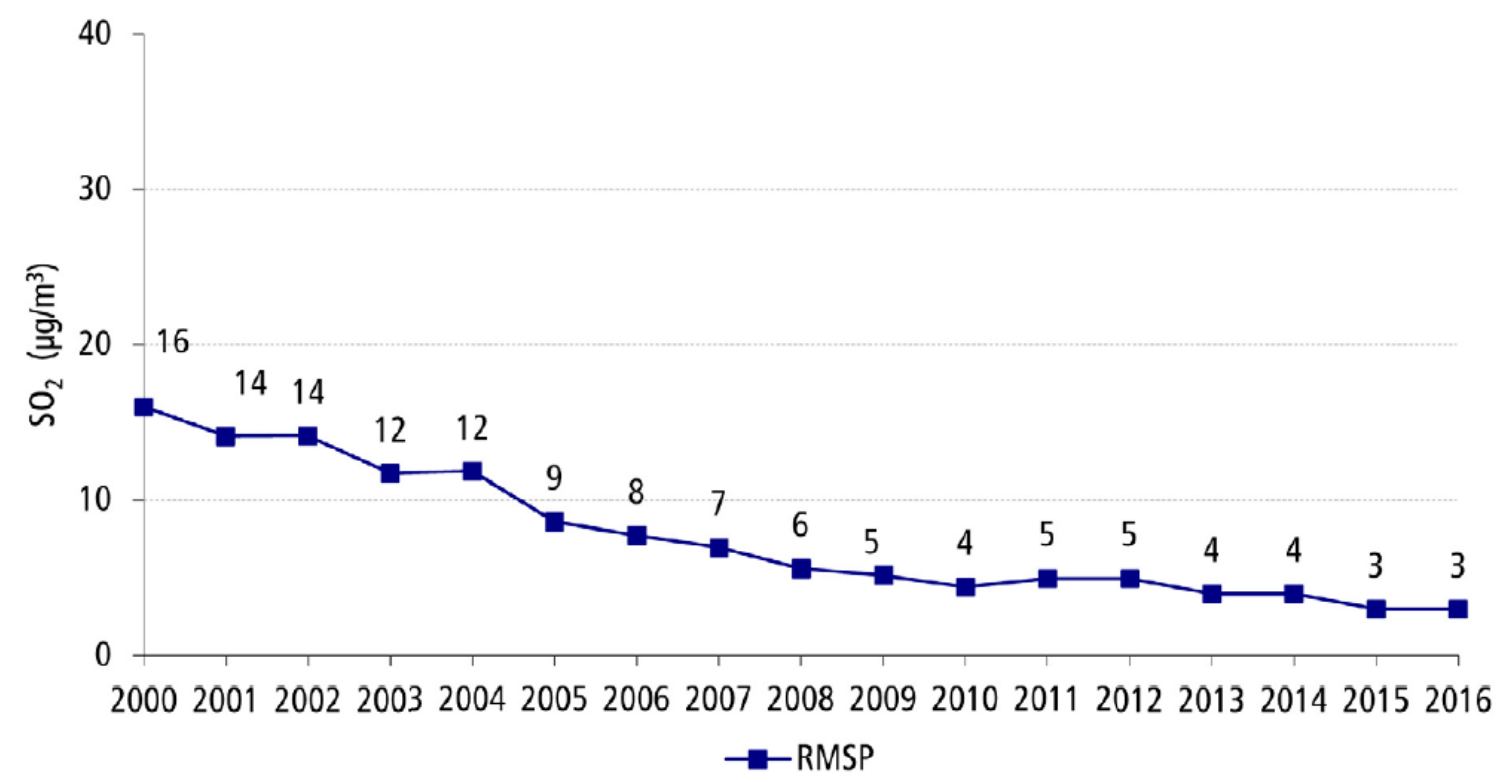

Figure $14-\mathrm{SO}_{2}$ - Evolution of annual average concentrations - RMSP

Source: Qualidade do ar no estado de São Paulo 2016

\section{CONCLUSION AND SUGESTIONS}

Through the various topics and evaluations made during this work, it is possible to conclude that there is an efficient work to improve atmospheric air in the State of São Paulo thanks to emissions legislation and improvements in fuels used in vehicles. However, it is necessary to continue and make further improvements as the fleet of vehicles continues to increase.

Here are the possible actions to be taken to reduce the levels of polluting gases in the air:

- Proper maintenance of vehicles

- Vehicle fleet renewal

- More Restrictive Legislation

- Decentralization of urban areas (vehicle routing and alternative routes from urban centers, improvement of infrastructure)

- Inspection of fuels at points of sale used in vehicles

- Constant monitoring of air quality in more Brazilian cities

There are now cities around the planet that already face serious problems with air pollution, bringing problems to the health of their populations. If the main Brazilian cities do not continue to deal seriously with this problem, it is possible that in the future we will have to face the same problems. 


\section{BIBLIOGRAPHIC REFERENCES}

[1] ALMEIDA, I. A Poluição atmosférica por material particulado na mineração a céu aberto. Tese de mestrado, São Paulo, Escola Politécnica da Universidade de São Paulo, 1999

[2] AZUAGA. Danos ambientais causados por veículos leves no Brasil. Tese de mestrado em Engenharia - UFRJ, 2000.

[3] BRAGA, A. et al. Poluição atmosférica e saúde humana. São Paulo, REVISTA USP, 2001

[4] CARVAlHO M. B. F. Poluição Atmosférica E Mudanças Climáticas. 2009. Disponível em:

http://www.pucrio.br/pibic/relatorio_resumo2009/relatorio/dir/mariana_carvalho.pdf Acesso em: 11-02-2013

[5] CETESB (São Paulo), Emissões veiculares no estado de São Paulo 2014, São Paulo, CETESB, 2015.

[6] CETESB (São Paulo), Qualidade do ar no estado de São Paulo 2016, São Paulo, CETESB, 2017.

[7] COELHO, S.Z.S.M. Uma análise estatística com vistas a previsibilidade de internações por doenças respiratórias em função de condições meteorotrópicas na cidade de São Paulo. 2007. Tese (Doutorado em Ciências) - Universidade de São Paulo. São Paulo, 2007

[8] FREITAS, C. et al. Internações e óbitos e sua relação com a poluição atmosférica em São Paulo, 1993 a 1997. Revista Saúde Pública, v.38, n.6, p.751-7, 2004.

[9] GOUVEIA, N. et al. Hospitalizações por causas respiratórias e cardiovasculares associadas à contaminação atmosférica no Município de São Paulo. Cadernos de Saúde Pública, Rio de Janeiro, v.22, n.12, p.2669-77, 2006.

[10] HEYWOOD, J. B., "Internal Combustion Engine Fundamentals. MCGraw-Hill series in mechanical engineering. Massachusetts, 1988.

[11] Lisboa H. M. e KAWANO M. Controle da Poluição atmosférica. Cap. IV monitoramento de poluentes Atmosféricos. dez 2007. Disponível em: <http://www.lcqar.ufsc.br/adm/aula/CapMonitoramentodaQUALIDADEDOAR.pdf> Acesso em: 11 jan. 2013

[12] TEIXEIRA, E. C; FELTES, S; SANTANA, E. R. R. Estudo Das Emissões De Fontes Móveis Na Região Metropolitana De Porto Alegre, Rio Grande Do Sul. Química Nova, Vol. 31, pag 244, 2008. 